\title{
An interdisciplinary approach to volcanic risk reduction under conditions of uncertainty: a case study of Tristan da Cunha
}

\author{
A. Hicks ${ }^{1}$, J. Barclay ${ }^{1}$, P. Simmons ${ }^{1}$, and S. Loughlin ${ }^{2}$ \\ ${ }^{1}$ Department of Environmental Sciences, University of East Anglia, Norwich Research Park, Norwich, Norfolk, NR4 7TJ, UK \\ ${ }^{2}$ British Geological Survey, Murchison House, West Mains Road, Edinburgh, EH9 3LA, UK
}

Correspondence to: A. Hicks (a.hicks@uea.ac.uk)

Received: 8 August 2013 - Published in Nat. Hazards Earth Syst. Sci. Discuss.: 23 December 2013

Revised: 18 June 2014 - Accepted: 19 June 2014 - Published: 28 July 2014

\begin{abstract}
The uncertainty brought about by intermittent volcanic activity is fairly common at volcanoes worldwide. While better knowledge of any one volcano's behavioural characteristics has the potential to reduce this uncertainty, the subsequent reduction of risk from volcanic threats is only realised if that knowledge is pertinent to stakeholders and effectively communicated to inform good decision making. Success requires integration of methods, skills and expertise across disciplinary boundaries.

This research project develops and trials a novel interdisciplinary approach to volcanic risk reduction on the remote volcanic island of Tristan da Cunha (South Atlantic). For the first time, volcanological techniques, probabilistic decision support and social scientific methods were integrated in a single study. New data were produced that (1) established no spatio-temporal pattern to recent volcanic activity; (2) quantified the high degree of scientific uncertainty around future eruptive scenarios; (3) analysed the physical vulnerability of the community as a consequence of their geographical isolation and exposure to volcanic hazards; (4) evaluated social and cultural influences on vulnerability and resilience; and (5) evaluated the effectiveness of a scenario planning approach, both as a method for integrating the different strands of the research and as a way of enabling on-island decision makers to take ownership of risk identification and management, and capacity building within their community.

The paper provides empirical evidence of the value of an innovative interdisciplinary framework for reducing volcanic risk. It also provides evidence for the strength that comes from integrating social and physical sciences with the development of effective, tailored engagement and communication strategies in volcanic risk reduction.
\end{abstract}

\section{Introduction}

In concert with the global acknowledgement that disaster risk reduction will only be effectively tackled by considering the physical risks alongside those presented by challenging social circumstances and decision making (e.g. IRDR Strategic Plan 2013-2017) it is now relatively widely acknowledged that advances in volcanic risk reduction research are contingent on the integration of social and physical sciencebased knowledge and approaches, and tailored communication methods (e.g. Barclay et al., 2008; Johnson, 2012). There have been innovative multidisciplinary studies oriented towards the reduction and mitigation of volcanic risk, by advancing understanding of important component challenges, for example, heterogeneous risk perceptions (Gregg et al., 2004; Gaillard, 2008; Haynes et al., 2008b; Paton et al., 2008), incorporation of traditional beliefs and knowledge (Cronin et al., 2004; Mercer et al., 2007; Donovan, 2010), the role of religion (Chester, 2005; Chester et al., 2008), effective risk and hazard communication (Haynes et al., 2007, 2008a), strategies to increase community resilience (e.g. Paton et al., 2001) and building sustainable livelihoods (Kelman and Mather, 2008). It is, however, very hard to find examples of single studies that adopt an integrated interdisciplinary approach to volcanic risk reduction.

This novel study developed an interdisciplinary approach that was applied on the island of Tristan da Cunha. The aim of this innovative research was to collect and analyse new data on both the physical and social components of volcanic risk, and integrate and communicate this knowledge using community-centred strategies. The objectives of this study were (i) to improve knowledge of the recent eruptive 


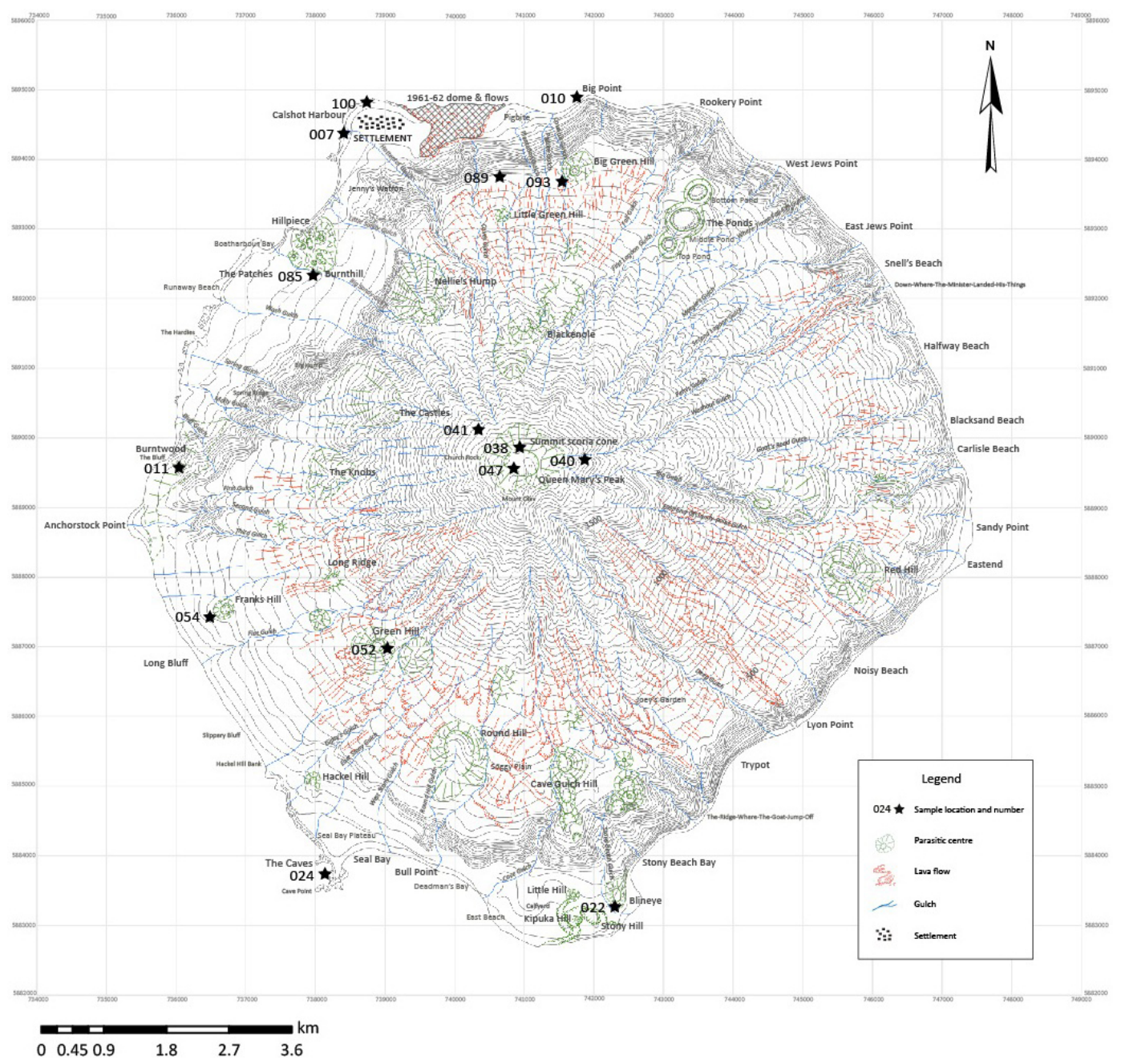

Figure 1. Map of Tristan da Cunha including sampling sites for ${ }^{40} \mathrm{Ar} /{ }^{39} \mathrm{Ar}$ dating. The Settlement is located in the north of the island (modified from Dunkley, 2002).

history and quantify uncertainty around future eruptive scenarios; (ii) to identify and understand the salient components of risk that would contribute to vulnerability and resilience, during and after a volcanic crisis; (iii) to enable a population at risk to consider and adopt both short- and long-term strategies that might reduce their risk from volcanic activity; and (iv) to monitor community response to new science communication, and make empirical observations of change.

\section{Case study: Tristan da Cunha}

Tristan da Cunha (Tristan) is a remote, active volcanic island in the South Atlantic. It is one of 14 Overseas Territories of the UK, and is home to a small population of $266^{1}$ people who reside in the north of the island as a single community (the Settlement; Fig. 1).

\footnotetext{
${ }^{1}$ Population correct as of June 2014.
}

There were several reasons to focus on Tristan: (i) it is an active volcano, typical of many small island volcanic settings, with the last eruption occurring within living memory (1961-1962) ${ }^{2}$ (Baker et al., 1964); (ii) the morphological evolution of the island and the eruptive history are not fully understood, so working on Tristan offered an opportunity to better define the eruptive history to refine future eruptive scenarios; (iii) it presented a case that was physically and socially well bounded, greatly simplifying analysis of the social processes and the communication of risk; and (iv) the relatively rich account of Tristan's short, yet eventful, history of Settlement (<200 years) (e.g. Brander, 1940) permitted analysis of how present-day vulnerabilities may reflect historic events and developments, and how current societal processes, community development, activities and

\footnotetext{
${ }^{2}$ Pumice washed up on Tristan beaches in 2004, thought to be sourced from a submarine eruption proximal to Tristan. The exact vent location could not be determined (Hards, 2004).
} 
new policies may affect vulnerability in the future (Lewis, 2009). It was important to analyse not only those characteristics that increase vulnerability to natural hazards, but also those that contribute to resilience. While island communities are often disproportionately vulnerable to the effects of natural hazards, they can also develop strong and successful coping mechanisms which can provide lessons in strengthening resilience elsewhere (e.g. Pelling and Uitto, 2001; Gaillard, 2007; Kelman, 2007). Therefore, a final objective was (v) to identify and analyse characteristics of resilience of Tristan islanders. Tristan is often mentioned as an example of small island resilience, in light of the islanders' return to Tristan following a two-year evacuation initiated by the 1961-1962 eruption; however the literature is underdeveloped thus far (Gaillard, 2007; Dibben and Chester, 1999).

The remainder of this section will provide a more in-depth description of Tristan's physical vulnerabilities, both to establish the problem and the importance of developing risk reduction measures on the island.

Situated over $2800 \mathrm{~km}$ WSW from Cape Town and over $3350 \mathrm{~km}$ from Rio de Janeiro, Tristan islanders are considered to be the most isolated population in the world. Causes of vulnerability on Tristan are rooted in the island's geographical location. Physical isolation has created disproportionate vulnerability to a spectrum of threats from natural hazards to societal, biological, ecological and economic risks. These threats can be amplified by the time it takes to obtain outside assistance and adequate resources to cope and recover. Further, the lack of habitable land on the island limits options for evacuation if the Settlement were to be threatened directly. As a high, steep mountain, Tristan's slopes rapidly transport material (e.g. water, rock, eruptive products) downhill, normally channelled via deeply incised gulches (canyons). Flash flooding is common following heavy, prolonged rainfall, yet there are currently no monitoring measures in place to determine the quantity of rainfall, record mass movements or assess slope instability. Sheer cliffs also make it difficult for islanders to safely access the mountain and would certainly prevent infirm islanders and many of the elderly from reaching the slopes of the volcano. In an event where the Settlement coastal strip were deemed uninhabitable, the only way for the entire population to be "safely" transferred to another part of the island, or elsewhere, would be by boat.

The only access to the island is by ship (a 7-10-day journey from Cape Town). This means that Tristan has very restricted access to aid resources and emergency health care. Further, dependence on one mode of transportation to and from Tristan controls external response time. In the event of a rapid-onset eruption, assistance could take many days to arrive, even if mobilised immediately. Rapid crisis response by either the Royal Navy or South African Navy would depend largely on location of available vessels. In addition to the handicap of delay and inconsistency, the limitations of transport by ship create further problems, in terms of the challenges of navigating in rough seas and poor weather, ability to evacuate possibly the entire population and the lack of direct access to Tristan's small harbour. Ships have to anchor offshore and dispatch inflatable boats for transferral of cargo and passengers. The Settlement's position is exposed to the prevailing north-west winds, which makes it vulnerable to frequent bad weather, preventing all but the highestpowered boats from leaving and accessing the island. Even if a ship could arrive in 2-3 days, therefore, access to Tristan is not guaranteed.

Location currently restricts Tristan from diversifying its economy. Since the fishing industry was established in 1949, Tristan has been exporting crayfish to US, European and Japanese markets, and approximately $78 \%$ of the economy depends on this single resource (E. Mackenzie, personal communication, 2009). Additional revenue is created through tourism and philatelic services, but there are limited options for livelihood diversification.

In terms of infrastructure vulnerability, the island's fish factory is the only building constructed with earthquake engineering or severe storm protection in mind. The distinct, twostorey structure was constructed to withstand wind speeds up to 100 knots and seismic activity up to 7.5 on the Richter scale $^{3}$. Due to the infrequency of volcanic eruptions and seismic activity, no other buildings have been constructed with a view to moderate the effects of likely eruptive products or seismicity. Therefore, buildings present several structural vulnerabilities to volcanic hazards and are of relatively high risk to occupants in the event of an eruption near to the Settlement. There is one hospital on the island, built in 1971, which has a small operating theatre and basic equipment equivalent to a mobile army hospital. Most small injuries or non-critical illnesses can be successfully dealt with, and visiting doctors are capable of undertaking minor surgical procedures. Many islanders $(>50 \%)$ are dependent on medication to alleviate symptoms of asthma and other bronchial conditions: genetic disorders which are thought to have afflicted five of the original settlers (Zamel et al., 1996; Slutsky et al., 1997). The hospital does not have the facilities to cope in the event of mass casualties.

Tristan has many natural springs, so water is plentiful. However, large-scale slope failure, tectonic or magmatic activity, for example, could alter the hydrological system, possibly contaminating water, reducing flow or stopping it altogether.

\section{Research design}

This study was conducted as a $\mathrm{PhD}$ project, and was designed from the outset to be interdisciplinary, combining both physical and social science methodologies in a way that could be carried out by a single researcher. This required the

\footnotetext{
${ }^{3}$ The Richter scale is a base 10 logarithmic scale, normally in the range of $<1-9$.
} 


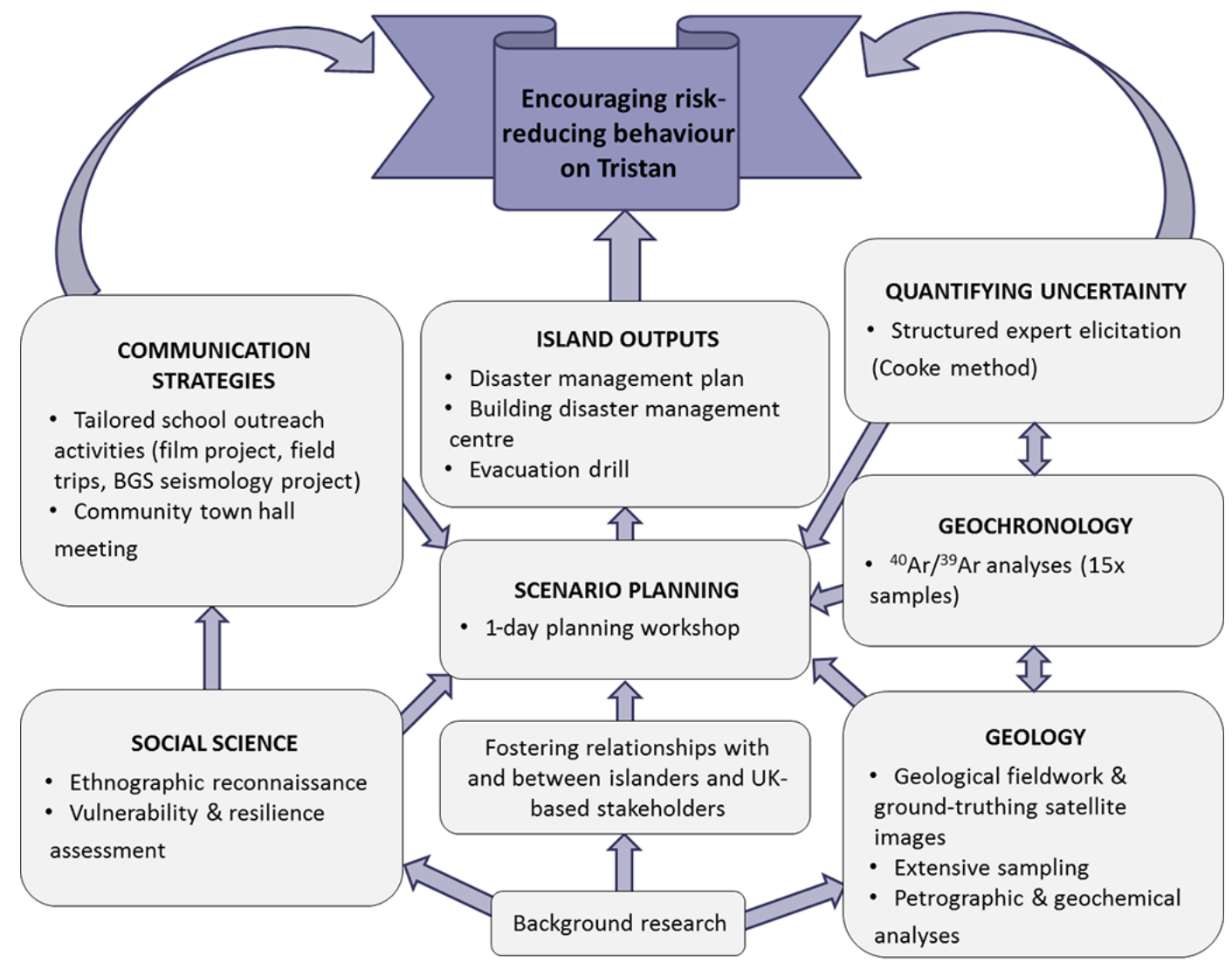

Figure 2. Schematic of interdisciplinary research components. The data-gathering phase involved collecting geological, geochronological, probabilistic and social information. These data then informed the action research phase, manifest as a scenario planning workshop.

researcher (Hicks) to develop competence in a number of different research fields ${ }^{4}$.

Figure 2 summarises the components of this research, and their relationships. Three strands of data were collected and analysed: (i) geological (volcanic stratigraphy and timing of volcanic events), (ii) probabilistic (quantification of the uncertainty of possible eruptive scenarios) and (iii) social (physical vulnerabilities and social and cultural influences on vulnerability and resilience). These three broad data strands provided the basis for development of a framework for interdisciplinary research, testable at virtually any volcanic setting. However, some of the more specific data sets and analyses within each strand (for example, the geochronology and expert elicitation) were chosen because of the nature of Tristan's uncertain natural environment and unique social challenges, and the extent of knowledge gaps in the literature.

\footnotetext{
${ }^{4}$ While this presents particular challenges for single-person interdisciplinary studies, there are challenges in common with the organisation of interdisciplinary team-based research. This will be discussed further in the concluding section.
}

An extended field campaign was designed around two 15week $^{5}$ seasons (referred to hereafter as "phases"). The primary objectives of the first phase were to establish trust with decision makers and other community members, make observations of community behaviours and volcanic activity, data gathering (physical and social) and sample collection. Results obtained from each strand of the research were integrated in the second phase, which was focussed around the dissemination, debate and presentation of the results of the study, primarily using scenario planning as a vehicle. This paper has been structured to summarise results from each phase chronologically.

It is important to note that to gain and maintain consent to the research, to achieve the research objectives and to contribute to disaster risk reduction on the island required engagement throughout the project with those responsible for making decisions and taking action in the face of a volcanic crisis. At the project outset, contact was made with the onisland administrator, who is the representative of the UK Foreign and Commonwealth Office (FCO), with the Tristan Island Council and with UK-based FCO officials, in order to

\footnotetext{
${ }^{5}$ September to December 2009 and December 2010 to March 2011.
} 
discuss project objectives and outputs, to identify their requirements and to map out the decision-making and implementation processes.

\section{Research methods}

During phase one, volcanological data gathering involved field mapping, geological sampling and analysis via ${ }^{40} \mathrm{Ar} /{ }^{39} \mathrm{Ar}$ geochronology, refining views about timing, style, location and likely patterns of activity (Hicks et al., 2012). Scientific uncertainty was quantified using an established structured elicitation technique ${ }^{6}$ (Cooke and Goosens, 1999), using volcanological data collected in phase one. The focus of the elicitation was on the likely location of a future eruption on Tristan, given unrest. Eighteen UK-based volcanologists, many of whom have experience providing scientific advice to decision makers, were elicited individually or in small groups (two-five people). The integration of these two research components guided the design of the scenarios for the planning workshop in the second phase.

Ethnographic reconnaissance methods were also employed during this initial data-gathering phase, particularly participant observation, purposeful conversations and semistructured interviews with islanders and island administrators (e.g. Wolcott, 1999). Historical records and relevant research data (e.g. Munch, 1964, 1970, 1971) were integrated with information gathered in the field about the community and their activities. This required the active involvement of community members as well as the engagement of decision makers to foster trust and gain access to information about social and cultural vulnerabilities. Given the cautiousness which many islanders exhibit towards "outsiders" (particularly those who are seeking information from them), gathering this information required considerable time spent learning and contributing to routine daily activities on-island. Rather than formal interviews, exploratory conversations were felt to be more appropriate to the circumstances. These were held almost always under informal circumstances and often within homes, or at social occasions with a larger group. Astute questioning and reflective listening enabled identification of current knowledge and perceptions of volcanic risk. No one particular person or viewpoint was relied upon more than another, and data sources were triangulated to cross-check accounts that were given.

Several methods were used to analyse and refine data gathered in the field following phase one. Community vulnerability and resilience were characterised within a simple capacities and vulnerabilities matrix (Anderson and Woodrow, 1989), which focusses on three broad, interrelated areas: physical/material, social/organisational and motivational/attitudinal. The matrix provides a practical approach

\footnotetext{
${ }^{6}$ Expert elicitation is a formalised quantitative method for quantifying uncertainty by weighting expert judgments using mathematical scoring rules to determine performance-based metrics.
}

to systematically and comprehensively assess community characteristics, with an aim to inform mitigation measures and disaster preparedness (Twigg, 2001). The spatial and temporal components of Holling's (2001) adaptive cycle informed an analysis of the changes within the community over time, as well as an indication of how those changes may have altered levels of resilience to risk. These analyses, integrated with interview and observational data, guided the approach of phase two, and informed content of communication strategies.

Results of the analysis were not fed back to stakeholders in a linear way, but tailored to engage different sections of the community (Table 3 ). To engage with on-island decision makers (i.e. the island council and administrator), a scenario planning workshop was designed as strategy to both communicate research results and to encourage decision makers to identify feasible adaptation strategies in order to strengthen existing risk reduction and island development plans. Three different eruption scenarios were "played out" and the impact of dynamic external factors were discussed. As this exercise essentially formed the core of the research, in that it was the vehicle used to integrate the results from each research strand, the method used and results will be explored in more depth in Sect. 6.

The results from phase one also highlighted the need for further raising volcanic risk awareness in the community, so two other engagement strategies were undertaken: firstly, to engage the wider adult community, a town hall event was held with islanders towards the end of phase two, which enabled presentation and discussion of research results and offered a platform for the community to pose questions; and, secondly, outreach activities were conducted with school students, including field trips, eruption analogy experiments and an oral history film project about the 1961 eruption which was designed to give students an opportunity to interview their grandparents to learn from their first-hand experience of what happened during that time, thus helping to retain social memory of the events.

\section{Analysis of factors contributing to risk}

The following three sections present a short summary of results from the geological, geochronological and probabilistic research components, which relate to research objective (i) and a longer analysis of the findings from the social science component, which relates to research objective (ii).

\subsection{Physiography of Tristan and timing of volcanic events}

Volcanic activity on Tristan is attributed to an intra-plate melting anomaly, known as the Tristan hotspot, rather than partial melting from the Mid-Atlantic Ridge, approximately $350 \mathrm{~km}$ eastward (Sleep, 1990). The Tristan hotspot is 
considered to have driven volcanism that created the Walvis Ridge and Rio Grande Rise as the South Atlantic Ocean opened up in the Early Cretaceous. Tristan is the latest surface manifestation of this melting anomaly.

Tristan has a roughly conical edifice, with a maximum diameter of $1200 \mathrm{~m}$ and rises $\sim 5500 \mathrm{~m}$ from the sea floor. The uppermost $2060 \mathrm{~m}$ is exposed subaerially and is composed of summit-sourced lavas and intercalated pyroclastics. Numerous parasitic cones, considered to be post-shield volcanism, are scattered across the flanks; many of them are breached by lava flows. The island is almost entirely volcanic, comprising mainly silica-undersaturated basanites to phonolites, and probably emplaced within the last $\sim 200 \mathrm{kyr}$ (Hicks et al., 2012; Dunkley, 2002; McDougall and Ollier, 1982). Young, low-lying coastal strips flank the northwestern and southern margins of the island. Situated on these strips are the two most recent subaerial eruptions (1961-1962 eruption and Stony Hill; Fig. 1), which were low volume leaks of tephri-phonolitic lava, manifest as domes and flows (Dunkley, 2002). A large sector collapse scar is evident in the north-west of the island, and was inferred by Holcomb and Searle (1991) to have an associated submarine avalanche of $\sim 150 \mathrm{~km}^{3}$.

Geochemical and isotopic studies of Tristan rocks suggest that lavas are derived from melting of a deep, heterogeneous source, forming basanitic magma bodies that undergo fractionation and mixing in shallow conduits and transitory chambers (Le Roex et al., 1990). Isotopic analyses of phonolitic pumice that erupted from a submarine vent in 2004 (O'Mongain et al., 2005) indicate that it was generated by rapid, extensive fractionation of a small parental magma body, unrelated to the 1961 tephri-phonolitic magma (Reagan et al., 2008). This further suggests that, rather than being dominated by one large chamber, magma is sourced rapidly from depth and siphons off into smaller, discrete magma pockets nearer the surface. Given this style of magmatism and the spatial heterogeneity of eruptive centres (Fig. 1), it was important to appraise the past eruptive phases of Tristan and to constrain the relative timings of the differing styles of volcanism in an attempt to forecast future eruption scenarios.

The ${ }^{40} \mathrm{Ar} /{ }^{39} \mathrm{Ar}$ method (Renne et al., 1997; Lanphere et al., 2007) was applied to 15 well-defined eruptions on Tris$\tan$ (Hicks et al., 2012). The aim of the new geochronology was to ascertain spatio-temporal relationships of recent volcanism, explore relative timings and frequency of eruptions and to establish if the most recent summit activity post-dated eruptions from the parasitic centres lower on the flanks.

From the new dates no spatio-temporal pattern to parasitic cone activity was found, and recent volcanism from these sites varied in style, volume and composition with time, unlike recent activity from other well-dated ocean island systems. The northern sector of the island was built rapidly ( $81 \pm 10 \mathrm{ka}$ to $34 \pm 1 \mathrm{ka}$ ) with the sector collapse occurring within a $14 \mathrm{kyr}$ period ( $34 \pm 1 \mathrm{ka}-26 \pm 5 \mathrm{ka})$; however the southern sector and summit cone appeared to have a longer evolution $(118 \pm 4 \mathrm{kyr}$ and $81 \pm 8 \mathrm{kyr}$ respectively). Therefore it is likely that the construction of the edifice was piecemeal, evolving with more spatial and temporal complexity than previously suggested. Activity at the summit was concurrent with recent parasitic centre activity on the flanks and coastal strips between $81 \pm 8 \mathrm{ka}$ and $5.2 \pm 1.1 \mathrm{ka}$. Given that the summit slopes are very steep, and the channelising nature of the gulches, the consequences of a summit eruption for the Settlement are different than an eruption on lower-lying areas. Although the two most recent eruptions occurred on low-lying coastal strips (1961-1962 dome and flows; Stony Hill dome and flows ( $\sim 200-300$ years BP)), the new temporal framework revealed that future eruption on the flanks, or from the summit, cannot be discounted (Hicks et al., 2012).

Detailed methodology and results of the new geochronology can be found in Hicks et al. (2012).

\subsection{Using expert judgement to constrain uncertainty}

The variability in volcanism on Tristan presents significant uncertainty in terms of anticipating future eruptive scenarios on Tristan. In an attempt to address this uncertainty, an expert elicitation exercise was conducted. Using the eruption record and results from field mapping, 18 volcanics experts were elicited on the likelihood of progression through an event tree which considered an eruption following unrest, the likelihood of an eruption and then the likely location of eruption. Opinions on the likely hazard and their impacts were elicited using a paired comparison analysis ${ }^{7}$. Given that Tristan is a relatively data-impoverished setting, a paired comparison analysis was more appropriate than extending the event tree to assign absolute probabilities to a multitude of uncertain eruptive scenarios (Hicks et al., 2014 ${ }^{8}$ ).

By using the structured elicitation and asking experts to provide their confidence limits on probabilistic estimates, we were able to use the Classical Model (a methodology to combine expert opinion, designed by mathematician Roger Cooke) to quantify expert uncertainty. This method weights expert judgements by using mathematical scoring rules to determine performance-based metrics (Cooke, 1991). By pooling weighted expert opinion, a representative group distribution is produced. This emergent consensus is seen as invaluable for decision support and encourages the creation of "one voice" (IAVCEI Protocol, 1999) (Aspinall and Cooke, $1998)^{9}$.

\footnotetext{
${ }^{7}$ Paired comparison is a technique used to produce a rank of preference by comparing pairwise sets of alternatives according to particular criteria. For the Tristan exercise, experts were asked to rank particular volcanic hazards in terms of likelihood of occurrence and likelihood of impact.

${ }^{8}$ Detailed methodology and results of the expert judgement exercise are forthcoming in 2014.

${ }^{9}$ The appeal for transparent handling of uncertainty in quantitative decision-making support is persistent, and the Cooke method
} 
Results indicated that the experts were extremely uncertain about whether unrest would lead to an eruption, and the location of future eruptions on Tristan. Table 1 shows the group distribution, presenting the median values and the spread of uncertainty ( 5 th and 95 th percentile) for each question posed. However, this severe uncertainty was not unexpected with the available information, given that Tristan has not evolved a dominant central vent preference. In the event of an eruption, the emergent consensus of the expert group was that the most likely broad location of eruption is the coastal strips and the least likely location is the summit. However, when presented with the new geochronological evidence proving that the summit had been active very recently (see Sect. 5.1), many experts expressed greater uncertainty about future eruptive scenarios on the island. The paired comparison exercise confirmed that experts were in agreement that earthquakes and rockfalls were the hazards most likely to impact the Settlement, whether the eruption was at the summit, on the flanks, on the coastal strips or from a submarine vent. This has implications for the Settlement in terms of damage to homes and risk to inhabitants, as buildings were not constructed to withstand all seismic activity. Pyroclastic density currents and base surges were considered least likely, probably given the apparent lack of those deposits in the stratigraphic record.

For Tristan, this level of uncertainty presented a further challenge in effective risk communication during the second phase. Lack of certainty can be misinterpreted as a lack of confidence or ability, possibly exacerbated in this instance by compiling the findings of unknowable and unseen "experts". Nonetheless, the description of this uncertainty was a necessary step in establishing openness, transparency and long-term trust (Poortinga and Pidgeon, 2003).

\subsection{Social, economic and cultural influences on vulnerability and resilience}

Here we refer to vulnerability and resilience as the characteristics of a person, group and/or their situation which negatively or positively influence resistance, coping capacity and recovery. On Tristan, both vulnerability and resilience to natural hazards are influenced by a complex network of social interaction and behaviours, some of which can be traced to recent developments within the community, and others which have historical roots. These are summarised in Table 2. The following three sections present evidence from the literature and new results from the ethnographic reconnaissance, conducted in phase one of the research.

\footnotetext{
- amongst other structured methods for obtaining and combining expert judgement - provides tools for doing so. A special issue of Reliability Engineering and System Safety on expert judgement provides a comprehensive collection of state-of-the-art methodologies (Cooke, 2008).
}

Table 1. Results from expert elicitation "event tree" exercise, conducted with 18 UK-based volcanologists. Median values for the group distribution are presented alongside the upper and lower bounds of the group uncertainty.

\begin{tabular}{|c|c|c|c|}
\hline & \multirow{2}{*}{$\begin{array}{l}\text { Median } \\
\text { value }\end{array}$} & \multicolumn{2}{|c|}{ Bounds of uncertainty } \\
\hline & & $\begin{array}{c}\text { Lower } \\
\text { value }\end{array}$ & $\begin{array}{l}\text { Upper } \\
\text { value }\end{array}$ \\
\hline \multicolumn{4}{|c|}{ Probability of eruption given unrest } \\
\hline Eruption & 55 & 3 & 90 \\
\hline No eruption & 45 & 10 & 96 \\
\hline \multicolumn{4}{|c|}{ Probability of eruption at each of four locations } \\
\hline Summit & 17 & 2 & 53 \\
\hline Flanks & 24 & 6 & 79 \\
\hline Coastal strips & 38 & 5 & 83 \\
\hline Submarine & 21 & 4 & 83 \\
\hline \multicolumn{4}{|c|}{$\begin{array}{l}\text { Probability of flank eruption being proximal } \\
\text { or distal to the Settlement }\end{array}$} \\
\hline Proximal & 11 & 0.3 & 46 \\
\hline Distal & 89 & 26 & 99 \\
\hline \multicolumn{4}{|c|}{$\begin{array}{l}\text { Probability of coastal strip eruption } \\
\text { being proximal or distal to the Settlement }\end{array}$} \\
\hline Proximal & 40 & 5 & 83 \\
\hline Distal & 59 & 13 & 96 \\
\hline
\end{tabular}

\subsubsection{An evolving economic and political landscape (1816-1961)}

Tristan was first discovered by Portuguese explorer Tristaõ d'Acunha in 1506 (e.g. Brander, 1940, and references therein) although the island was not permanently inhabited until the withdrawal of a British garrison in 1816. Those few that chose to remain on Tristan created a community based on principles of communal ownership, integrity and equality. There was no chain of command or official leaders, and all produce and profits were shared equally. This founding vision is a significant marker in Tristan's history as the cultural homogeneity that accompanied these established values and principles has helped to generate plentiful stocks of social capital $^{10}$, mainly founded on strong community bonds and reciprocal behaviour (Table 2 ).

From 1890, the whaling industry declined, and the shortage of passing ships forced the islanders to modify their barter economy to one of subsistence (and increased selfsufficiency), in order to cope (Table 2). There were several decades of hardship, until the British Royal Navy established a garrison on Tristan during World War II, bringing with it a cash economy, new jobs, infrastructure (e.g. school,

\footnotetext{
${ }^{10} \mathrm{~A}$ concept that brings attention to the role of social interactions in explaining individual and collective outcomes.
} 
Table 2. Economic, social and cultural influences on vulnerability $(V)$ and resilience $(R)$, and their dynamics since Settlement.

\begin{tabular}{|c|c|c|c|c|}
\hline & & \multicolumn{3}{|c|}{ Time periods } \\
\hline & & Historical (1817-1961) & Eruption and evacuation (1961-1963) & Post-eruption (1963-2013) \\
\hline \multicolumn{5}{|c|}{ Social and cultural influences } \\
\hline \multirow[t]{2}{*}{ Governance } & $R$ & $\begin{array}{l}\text { Anarchist until WW2 (formal } \\
\text { administration introduced in 1950); } \\
\text { creation of the first island council } \\
\text { (1951) }\end{array}$ & Under UK governance & $\begin{array}{l}\text { UK links provide source of financial } \\
\text { and decision-making support }\end{array}$ \\
\hline & $V$ & $\begin{array}{l}\text { De-traditionalisation brought about by } \\
\text { formal administration }\end{array}$ & & Reliance on support \\
\hline \multirow[t]{2}{*}{ Economy } & $R$ & $\begin{array}{l}\text { Barter (with passing ships) with shared } \\
\text { profits; gradually moving to increased } \\
\text { subsistence and independence; } \\
\text { introduction of cash wages (1942); } \\
\text { exploitation of crayfish (1948) }\end{array}$ & Under UK governance & $\begin{array}{l}\text { Crayfish industry excellent cash "crop"; } \\
\text { increased revenue from tourism in } \\
\text { recent years }\end{array}$ \\
\hline & $V$ & $\begin{array}{l}\text { Crayfish canning factory destroyed by } \\
\text { lava flow (1961) }\end{array}$ & & $\begin{array}{l}\text { Effectively a single "crop" economy } \\
\text { (crayfish) which itself is susceptible } \\
\text { both to fluctuating markets and } \\
\text { ecological threats; increase in number } \\
\text { of patients requiring medical treatment } \\
\text { in Cape Town presents economic } \\
\text { burden }\end{array}$ \\
\hline \multirow[t]{2}{*}{$\begin{array}{l}\text { Livelihood } \\
\text { diversification }\end{array}$} & $R$ & $\begin{array}{l}\text { Barter (with passing ships), gradually } \\
\text { moving towards subsistence }\end{array}$ & Offered paid work; learned new skills & $\begin{array}{l}\text { All maintain potato patches; many } \\
\text { islanders have multiple roles (as most } \\
\text { jobs are weather-dependent) }\end{array}$ \\
\hline & $V$ & No options for diversification & & Limited options for diversification \\
\hline \multirow[t]{2}{*}{ Social capital } & $R$ & $\begin{array}{l}\text { Development of community based on } \\
\text { communal ownership, integrity and } \\
\text { equality; community engage in } \\
\text { collective action; building trust; } \\
\text { determination to remain on Tristan } \\
\text { despite hardship }\end{array}$ & $\begin{array}{l}\text { Strengthened cohesion from outside } \\
\text { exposure; weakened social } \\
\text { subordination to outsiders; increased } \\
\text { self-identity and confidence }\end{array}$ & $\begin{array}{l}\text { Strong kinship ties; retained original } \\
\text { values of equality, mutual aid and } \\
\text { selective reciprocity }\end{array}$ \\
\hline & $V$ & & & $\begin{array}{l}\text { Communications and media altering } \\
\text { interaction }\end{array}$ \\
\hline \multirow[t]{2}{*}{ Cultural capital } & $R$ & $\begin{array}{l}\text { "The Agreement" - shared values and } \\
\text { principles; community engage in } \\
\text { collective action; development of their } \\
\text { own, new, culture }\end{array}$ & Developed greater cultural confidence & $\begin{array}{l}\text { Sound sense of place; pride in heritage; } \\
\text { maintain traditional annual events }\end{array}$ \\
\hline & $V$ & & & $\begin{array}{l}\text { Modernism and modern } \\
\text { communication undermining cultural } \\
\text { characteristics }\end{array}$ \\
\hline \multirow[t]{2}{*}{$\begin{array}{l}\text { Health and } \\
\text { well-being }\end{array}$} & $R$ & $\begin{array}{l}\text { Initially very good; plentiful food (until } \\
\text { end } 19 \text { th C); illness rare due to lack of } \\
\text { visitors }\end{array}$ & Access to good medical facilities & $\begin{array}{l}\text { All islanders frequently work at the } \\
\text { Patches; fishing and building are } \\
\text { labour-intensive }\end{array}$ \\
\hline & $V$ & $\begin{array}{l}\text { Regularly in a state of privation from } \\
\text { end } 19 \text { th C to WW2 }\end{array}$ & No immunity; illnesses common & $\begin{array}{l}\text { Most have asthma or other bronchial } \\
\text { conditions; weakened immune systems } \\
\text { from common infections; high level of } \\
\text { diabetes; importing more food; increase } \\
\text { in sedentary jobs; increase in motor } \\
\text { vehicles; aging population }\end{array}$ \\
\hline \multirow[t]{2}{*}{ Marginalisation } & $R$ & $\begin{array}{l}\text { Isolation also positive (improved } \\
\text { oping strategies); became less } \\
\text { marginalised during WW2 }\end{array}$ & $\begin{array}{l}\text { Many adapted rapidly to a new way of } \\
\text { life }\end{array}$ & $\begin{array}{l}\text { Annual visit from Gough Island relief } \\
\text { vessel (1980s onwards); increase in } \\
\text { shipping; more tourism; better links } \\
\text { with outside world }\end{array}$ \\
\hline & $V$ & $\begin{array}{l}\text { Extremely isolated - almost no } \\
\text { assistance available; risks taken to } \\
\text { meet with passing ships }\end{array}$ & $\begin{array}{l}\text { Thrust into public eye; probing } \\
\text { journalists and researchers; } \\
\text { experienced crime; kept a degree of } \\
\text { marginalisation as lived together on an } \\
\text { army base }\end{array}$ & Declining self-sufficiency \\
\hline
\end{tabular}


Table 2. Continued.

\begin{tabular}{|c|c|c|c|c|}
\hline & & \multicolumn{3}{|c|}{ Time periods } \\
\hline & & Historical (1817-1961) & Eruption and evacuation (1961-1963) & Post-eruption (1963-2013) \\
\hline \multicolumn{5}{|c|}{ Social and cultural influences } \\
\hline \multirow[t]{2}{*}{$\begin{array}{l}\text { Infrastructure } \\
\text { and resources }\end{array}$} & $R$ & $\begin{array}{l}\text { Arrival of "shipwrecked" sailors with } \\
\text { carpentry skills led to building of } \\
\text { longboats; WW2 onwards - } \\
\text { construction of modern amenities, } \\
\text { including sanitation, school, wireless } \\
\text { station, store, hospital (1942-1946); } \\
\text { technical and agricultural improvements; } \\
\text { canning factory built (1949) }\end{array}$ & N/A & $\begin{array}{l}\text { Improved roads and buildings; new } \\
\text { fishing factory built (2009); } \\
\text { underground cabling installed (2013) }\end{array}$ \\
\hline & $V$ & $\begin{array}{l}\text { Gradual reduction in traditional } \\
\text { methods }\end{array}$ & & $\begin{array}{l}\text { Frequent repair of only harbour } \\
\text { (ongoing); most buildings vulnerable to } \\
\text { seismic activity; one route out of } \\
\text { the Settlement; reliance on modern } \\
\text { equipment; suboptimal hospital } \\
\text { facilities }\end{array}$ \\
\hline \multirow[t]{2}{*}{ Communications } & $R$ & Increasing links with outside world & Rapid introduction to modernism & $\begin{array}{l}\text { Good links with outside world; cheap } \\
\text { telephony (2006); television (2001); } \\
\text { wireless internet (2009); uptake of } \\
\text { social media (2011) }\end{array}$ \\
\hline & $V$ & $\begin{array}{l}\text { Effectively cut off from the outside } \\
\text { world from } 1817 \text { to WW2 }\end{array}$ & & Reduction in community interaction \\
\hline Migration & $R$ & $\begin{array}{l}\text { Arrival of shipwrecked sailors who } \\
\text { brought new knowledge, techniques } \\
\text { and expertise (e.g. longboat building) } \\
\text { Mass outmigration from } 1890 \text { - } \\
\text { population of just } 50 \text { in } 1892 \text { - } \\
\text { community almost deemed } \\
\text { unsustainable }\end{array}$ & $\begin{array}{l}11 \text { of } 264 \text { islanders stayed in the UK } \\
\text { following the evacuation }\end{array}$ & $\begin{array}{l}\text { Earnings comparatively low (to Europe } \\
\text { and S. Africa), therefore limited options } \\
\text { for emigration; not possible to gain } \\
\text { formal qualifications on-island; scheme } \\
\text { in place for further education off-island } \\
\text { (all seen as both a vulnerability } \\
\text { (entitlements) but also resilience } \\
\text { (retaining and honing capacity) }\end{array}$ \\
\hline
\end{tabular}

shop, hospital) and permanent contact with the outside world (wireless station). These transformations began to erode the anarchist form of social organisation and was replaced by a more formal and structured system (British administration; Table 2). The first contracted resident British administrator became the head of government on Tristan in 1950, followed shortly by the creation of the first island council (the first chief islander was not appointed until 1970). While outside support strengthened resilience in some ways, for example by construction of a hospital and improved sanitation, the erosion of traditional social practices and introduction of hierarchy may have weakened it.

The success of the fishery, built in 1948 to exploit the crayfish resource, brought technical and agricultural improvements (e.g. modern sanitation and effective grazing methods). Islanders were able to purchase "luxury" goods and thus raise their standards of living in line with those of the "outside world" (Munch, 1964). However, this came at a cost as greater dependence on imports further affected traditional forms of social and cultural practice and organisation.

\subsubsection{Social impact of eruptive activity (1961-1963)}

In October 1961, a new volcanic dome began to extrude just to the east of the Settlement. Initially, the entire population (264 islanders) evacuated to an area $3 \mathrm{~km}$ west of the Settlement where the islanders grow potatoes and other vegetables, known as "the Patches", but as volcanic activity intensified, the population evacuated to nearby uninhabited Nightingale Island and eventually onwards to Southampton, England (via South Africa).

During the ethnographic survey, some islanders commented on their willingness and ability to rapidly adapt to new lifestyles in England (Table 2), although many islanders reflected on the challenges of adjustment, particularly crime, probing journalists and medical researchers, poor weather and lack of immunity to common ailments. When eruptive activity on Tristan began to wane in March 1962, the islanders submitted a petition to the Colonial Office to return to their home, which remained unanswered. Upon hearing that 12 men had travelled back to Tristan to begin the repair effort, financed solely by the community, the Colonial Office consented for the islanders to return. The move was finally completed in 1963 when the last of the islanders departed the UK. Eleven islanders remained in England. 
During the ethnographic survey, many islanders commented that, had the Colonial Office (now the Foreign and Commonwealth Office) not kept the community together in one location, resettlement on Tristan would have been unlikely. By staying together, the community developed stronger bonding ties, and defended much of their cultural identity, although certain changes were inexorable. Regardless of being submersed in an unfamiliar, hierarchical society for two years, the islanders retained their original values of equality, mutual aid and selective reciprocity - principles that prevail today.

\subsubsection{External influences on vulnerability and resilience (1963-2013)}

At the time of the ethnographic survey ${ }^{11}$ the Tristan community was characterised by a small, cohesive population organised according to kinship. Social solidarity remains strong. For example, communal small-holding work at the Patches continues and is seen as an important part of Tristan's heritage and an expression of kinship activity. The original principles of communal ownership and equality are reflected in the management and distribution of the Patches, as every member of the community has an equal share of the land and livestock, and plots at the Patches are shared out amongst families. Family bonds and cooperative kinship networks were vital when hardship was most pressing in the past, and these sustained relationships still offer a rich source of social capital and an essential means for the population to absorb stress. The islanders' resilient qualities have been essential to overcoming not only the impact of the 1961 eruption but also the damaging effects of more recent natural and accidental events, such as a severe storm in 2001, a factory fire in 2008 and frequent storm damage to the harbour.

While collective activity is still widespread, however, there is a sense that, in cultural terms, the community is gradually returning to the "atomism" of pre-1961 culture. This can be seen in the trend of working independently or as family units, which has been accompanied by declining self-sufficiency as the islanders become more dependent on imported food and consumer goods.

One significant influence has been the recent introduction of modern media, technology and communications to Tristan, which has resulted in transformations in the community, especially affecting patterns of interaction (Table 2). New media and technological innovations may not be the sole explanation for social change, but they appear to have been a major contributing factor. From a vulnerability perspective however, it is important to consider the consequences of these social changes for community cohesion and stocks of social capital, in the face of a volcanic crisis (e.g. Pelling and High, 2005). Social capital has been recognised as an important

\footnotetext{
${ }^{11}$ September to December 2009 and December 2010 to March 2011.
}

indicator of resilience to natural hazards (and other risks) and is used to explicate some of the reasons why certain communities thrive and others fracture (Coleman, 1990; Putnam, 1993, 2000; Murphy, 2007; Rubin and Rossing, 2012). Although recovery from extreme events has depended - and will continue to depend - on administrative, financial and material support from the UK Government, a progressive decline in social capital over the longer term is likely to erode collective capacities to respond to and recover from volcanic activity. While at present any adverse effect on resilience appears to be negligible, as indicated by the persistence of a clear sense of community and collective capacities to cope with adverse events, social change needs to be considered in forward planning for disaster risk reduction.

Modernisation has also led to the loss of many customary practices, especially knowledge of traditional crafts and skills such as sailing and thatching. While the adoption of modern tools and equipment has improved productivity and efficiency, these often require complex maintenance which cannot always be accomplished by islanders. Reliance on new technologies can also bring unforeseen sources of vulnerability. For example, the evacuation in 1961 was only possible by transferring islanders to Nightingale Island in traditional locally crafted longboats. These could be launched from the beach even in poor sea conditions. The modern, motorised vessels in use today can only be launched from the harbour, which can be closed in bad weather, therefore introducing greater dependency on good weather conditions for evacuation.

For the population of Tristan to sustain its resilience to natural hazards, the maintenance of relevant community capacities, including stocks of social capital and of skills, is vital. A history of reciprocity has fostered understanding of the different capacities of individuals. In the event of a disaster, individual roles, responses and actions are assumed; islanders rapidly self-organise. There has been little need for pre-determined responsibilities. Working with the island council, who had detailed knowledge of community capacities, was therefore crucial to the success of the project.

\section{From science to decision making: scenario planning exercise}

Thus far, we have presented the results of physical and social components of the research, and while the separate streams of data were collected synchronously, integration of the outputs of the two sets of analysis was achieved at the scenario design phase and via the planning workshop.

One of the core research objectives (objective iii, Sect. 1) was to help increase the capacity of the Tristan Island Council and, consequently, the wider community, to act to reduce risk under conditions of uncertainty. While the absence of certainty is central to the difficulties of framing, quantifying and communicating risk to decision makers, effective 
risk communication to wider stakeholders groups must also appropriately handle uncertain information. This presents a challenge not only to volcanology but also to those engaged in developing and communicating volcanic risk reduction strategies.

To help communicate the high uncertainty of future eruptive scenarios, and to attempt to empower the community to prepare, scenario planning was selected as an appropriate vehicle to disseminate and discuss research results. This choice of method was reinforced by the work of Stirling $(2003,2010)$, who examines the consequences of incomplete knowledge for the effectiveness of analytical methods such as quantified risk assessment or expert consensus, distinguishing between incomplete knowledge about probabilities and about consequences and identifying methodological options which may be more appropriate to different epistemic conditions (Fig. 3).

In the case of Tristan, existing geological knowledge, combined with the new geochronology and field data produced by this research, meant that it was possible to present knowledge of a discrete set of outcomes, thus approaching the "unproblematic" end of the "consequences" axis. There was however limited basis on which to define probabilities of future eruptive scenarios; our knowledge of risk was therefore at the "problematic" end of that axis. These conditions suggested, following Stirling's schema, that a scenario-based methodology would be one of the most appropriate techniques to employ.

\subsection{Engagement via scenario planning}

Engaging decision makers was focussed around two meetings with the island council, firstly a presentation and discussion of results, and secondly a scenario planning workshop. Adopting this incremental approach was vital in establishing trust between the researcher (Hicks) and the island council.

Results from the research were presented in the first meeting to enable discussion around the volcano and the attendant scientific uncertainty, new observations from the current study and their implications for risk management. During the session, council members reflected on the difficulties involved in forecasting under uncertain conditions, and voiced concerns about having to wait for signs of volcanic unrest (if at all) before scientists could refine opinion. Given the challenges of geographical dissociation and the possibility of rapid onset of volcanism, the group realised the importance of on-island preparedness. At this point, the concept of scenario planning was introduced as a useful tool for developing response strategies.

Scenario planning is a way of engaging people in a "thinking" process to understand possible and plausible future events in relation to the position of distinct stakeholder groups. By considering the responsibilities, attitudes and assumptions of separate groups during an imagined crisis in terms of, for example, uncertainty, resources and/or politics,

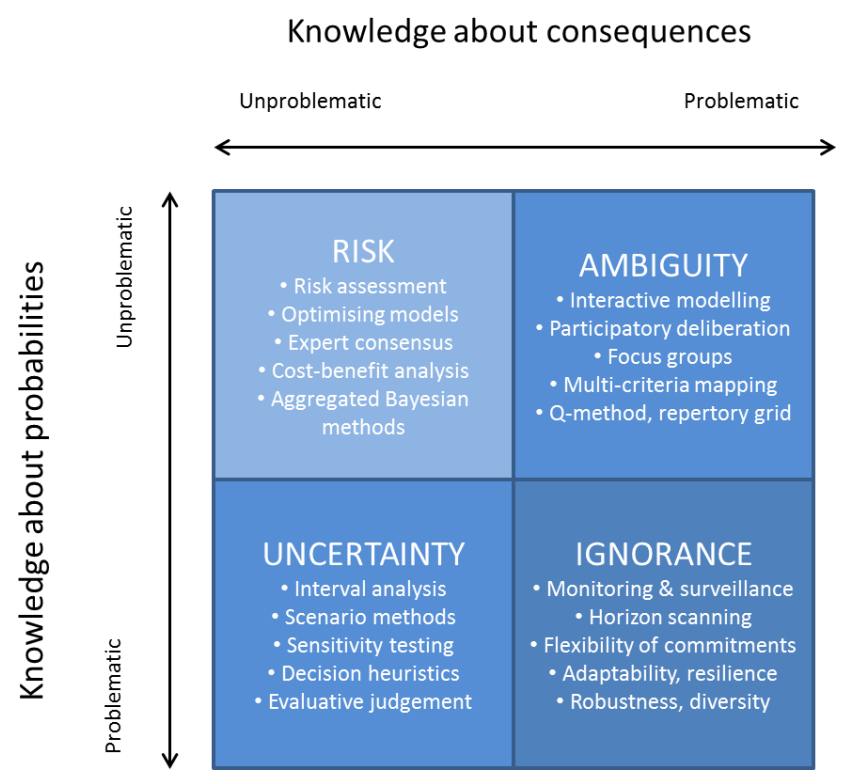

Figure 3. Methodological options for different epistemic conditions. Axes distinguish ways in which knowledge about risk may be incomplete and refer to the challenge posed by each category of incertitude for classical scientific approaches. For example, while quantification of uncertainty may be a useful tool when consequences are understood and there is good basis for assigning probabilities, it may have little relevance in situations that are characterised by ambiguity and ignorance. Adapted from Stirling (2010).

this can enable those involved to identify what questions need to be asked, and of whom, as well as to design strategies to protect communities from the worst consequences. This deliberative style of analysis presents a suitable way of engaging with people and communities who have not considered uncertain and/or seemingly incredible visions of the future, and whose thoughts are rooted in more immediate, everyday concerns.

In this study, Hicks designed and ran the scenario planning exercise in February 2011. Eight scenarios were produced, given a relative risk level, and presented to the workshop participants (Table 4). The vulnerable and resilient characteristics identified from the phase one analysis (Table 3 ) were built into the scenario dialogue and posed as questions at relevant moments (see "question prompts" in Table 5).

The group selected three scenarios to play out: a best, most likely and reasonable worst case (Tables 4 and 5). Worst cases are normally taken from the historical record, but due to the short history of settlement on Tristan, worst cases were taken from the stratigraphic record and knowledge of plausible eruptive behaviour on analogous volcanic ocean islands. This made it clear to the group that the worst can happen with no historic precedent on which to draw.

Each scenario developed as a narrative, enabling participants to imagine responding to particular events. The progress of the scenario was "frozen" at key points to allow 
Table 3. Description and evaluation of communication strategies employed on Tristan da Cunha.

\begin{tabular}{|c|c|c|c|c|}
\hline & Exercise & $\begin{array}{l}\text { Involvement and } \\
\text { uptake }\end{array}$ & Response and feedback & Adaptation \\
\hline A & $\begin{array}{l}\text { Overview of } \\
\text { eruptive history and } \\
\text { transparent } \\
\text { discussion of } \\
\text { uncertainty }\end{array}$ & $\begin{array}{l}\text { Twelve island council } \\
\text { members; island } \\
\text { administrator; disaster } \\
\text { management (DM) } \\
\text { coordinator }\end{array}$ & $\begin{array}{l}\text { (i) Group reflection of difficulties involved in eruption } \\
\text { forecasting under uncertain conditions } \\
\text { (ii) Concerns raised about having to wait for signs of } \\
\text { volcanic unrest (if at all) before refining of scientific } \\
\text { opinion } \\
\text { (iii) Realisation of the importance of on-island } \\
\text { preparedness } \\
\text { (iv) Initiation and design of evacuation exercise } \\
\text { (v) Commitment to scenario planning exercise }\end{array}$ & (i) Update of DM plan \\
\hline B & $\begin{array}{l}\text { Town hall } \\
\text { (summarised and } \\
\text { tailored version of } \\
\text { A); discussion of } \\
\text { evacuation exercise }\end{array}$ & $\begin{array}{l}\text { Community members } \\
(\sim 55 \% \text { attendance })\end{array}$ & $\begin{array}{l}\text { (i) No questions raised about volcanic hazards and risk } \\
\text { (ii) Instead, meeting provided a platform for community to } \\
\text { raise questions about evacuation drill } \\
\text { (iii) Sense of misunderstanding and resistance about the } \\
\text { rationale for building a DM centre }\end{array}$ & $\begin{array}{l}\text { (i) Preparation of personal } \\
\text { emergency supply kits }\end{array}$ \\
\hline $\mathrm{C}$ & Evacuation exercise & $\begin{array}{l}\text { Community members } \\
\text { (95\% attendance) }\end{array}$ & $\begin{array}{l}\text { (i) Feedback largely positive } \\
\text { (ii) Minority voiced dissatisfaction and failed to } \\
\text { understand its purpose (not aided by incompletion of DM } \\
\text { centre) } \\
\text { (iii) Drill highlighted a number of defects in the evacuation } \\
\text { plan }\end{array}$ & $\begin{array}{l}\text { (i) Significant improvements } \\
\text { to evacuation drill } \\
\text { (ii) Alteration and clarification } \\
\text { of roles } \\
\text { (iii) Desire to repeat drill } \\
\text { annually }\end{array}$ \\
\hline $\mathrm{D}$ & $\begin{array}{l}\text { School outreach } \\
\text { initiatives }(2 \times \text { earth } \\
\text { science lessons } \\
\text { (including BGS } \\
\text { school } \\
\text { seismometer } \\
\text { project); } 2 \times \text { island } \\
\text { field trips; } \\
\text { documentary film } \\
\text { project) }\end{array}$ & $\begin{array}{l}\text { Twelve pupils from } \\
\text { St. Mary's School; } \\
\text { education adviser }\end{array}$ & $\begin{array}{l}\text { (i) High level of engagement, although challenging to } \\
\text { extract feedback } \\
\text { (ii) Regular inspection of helicorder data } \\
\text { (iii) Other interested islanders present for visit to } 1961 \\
\text { dome (field trip } 1 \text { of 2) } \\
\text { (iv) Students involved in data collection (fumarole } \\
\text { observations and temperature measurements) } \\
\text { (v) Filmed interviews arranged (by students) with four } \\
\text { elderly islanders }\end{array}$ & $\begin{array}{l}\text { (i) Alterations to school } \\
\text { curriculum to include } \\
\text { geophysical hazards and } \\
\text { disaster risk reduction themes, } \\
\text { and new data about the } \\
\text { eruptive history for the "Tristan } \\
\text { Studies" module }\end{array}$ \\
\hline $\mathrm{E}$ & $\begin{array}{l}\text { Scenario planning } \\
\text { exercise }\end{array}$ & $\begin{array}{l}\text { Eight island council } \\
\text { members; island } \\
\text { administrator; disaster } \\
\text { management } \\
\text { coordinator }\end{array}$ & $\begin{array}{l}\text { (i) Brief initial hesitation of voicing opinions (island } \\
\text { administrator obliged to dominate conversation) } \\
\text { (ii) Desire to reduce scientific uncertainty } \\
\text { (iii) Recommendation to provide and support effective } \\
\text { early warnings by real-time monitoring (deployment of } \\
\text { further equipment required, e.g. seismometer array and } \\
\text { strainmeters) } \\
\text { (iv) Realisation of importance of increasing on-island } \\
\text { capability } \\
\text { (v) Recommendations for protocol amendments, } \\
\text { infrastructure and resource improvements }\end{array}$ & $\begin{array}{l}\text { (i) Design changes to DM } \\
\text { centre } \\
\text { (ii) Alterations to DM plan } \\
\text { (particularly clarification of } \\
\text { roles) } \\
\text { (iii) Addition of scenario } \\
\text { planning exercise to decision- } \\
\text { making processes } \\
\text { (iv) Active exploration of } \\
\text { Nightingale Island as possible } \\
\text { evacuation site (desalinisation } \\
\text { solutions) } \\
\text { (v) Plan to repeat evacuation } \\
\text { exercise (altering scenario) }\end{array}$ \\
\hline $\mathrm{F}$ & $\begin{array}{l}\text { One-to-one } \\
\text { conversations } \\
\text { with islanders }\end{array}$ & $\begin{array}{l}\sim 60 \% \text { of community } \\
\text { members }\end{array}$ & $\begin{array}{l}\text { (i) Gratitude for contact } \\
\text { (ii) Appreciation for individual-level communication - felt } \\
\text { able to ask questions and voice opinions freely }\end{array}$ & $\begin{array}{l}\text { (i) Preparation of personal } \\
\text { emergency supply kits }\end{array}$ \\
\hline G & $\begin{array}{l}\text { Bi-annual meetings } \\
\text { with officials at the } \\
\text { Foreign and } \\
\text { Commonwealth } \\
\text { Office }\end{array}$ & $\begin{array}{l}\text { Tristan da Cunha and } \\
\text { Pitcairn desk } \\
\text { officer(s); FCO } \\
\text { adviser; PhD } \\
\text { supervisory team } \\
\text { (including head of } \\
\text { volcanology at the } \\
\text { British Geological } \\
\text { Survey) }\end{array}$ & $\begin{array}{l}\text { (i) Discussion of plans for DM improvements; building } \\
\text { DM centre } \\
\text { (ii) Request for report summarising research findings, plus } \\
\text { recommendations } \\
\text { (iii) Support of new collaborative project between volcanic } \\
\text { risk and economics researchers, FCO and Tristan } \\
\text { Government (recently funded) }\end{array}$ & $\begin{array}{l}\text { (i) Temporary lengthening of } \\
\text { DM coordinator contract to } \\
2012 \\
\text { (ii) Volcanic risk put into long- } \\
\text { term planning for island }\end{array}$ \\
\hline
\end{tabular}


Table 4. Eight scenarios presented for deliberation at the planning workshop. Each scenario has a relative risk level which was allocated by acknowledging the size of the eruption in the scenario, proximity to the Settlement, speed of onset, quantity and type of precursory signs and signals. Volcanological terminology (e.g. scoria cone) were introduced at the first council meeting. Use of the term "the volcano" was used to reflect locally accepted terminology for the 1961-1962 eruption, and just "volcano" for an eruption. Chosen scenarios to "play out" are in italic.

$\begin{array}{lll}1 & \text { Dome growth and lava flows just to the west of the volcano. Preceded by } 2 \text { months of earthquakes (repeat of 1961). } & \text { MEDIUM } \\ 2 & \text { Six hours of earthquakes followed by a submarine eruption. Pumice seen to west of the Settlement (repeat of 2004). } & \text { LOW } \\ 3 & \text { Scoria cone growth on the Base above the Settlement, subsequent breaching by lava flow. No earthquake warning. } & \text { MEDIUM } \\ 4 & \text { Maar formation (large explosions that form deep craters like the Ponds) on the Base near Big Gulch. No warning. } & \text { MEDIUM } \\ 5 & \text { Dome growth and lava flows near the Caves. Earthquakes only felt by those in the south. } & \text { LOW } \\ 6 & \text { Large, explosive eruptions from the summit; volcanic bombs reaching the edge of the Base. Ash clouds erupted and } & \text { HIGH } \\ & \begin{array}{l}\text { some ground collapse. Two weeks of earthquakes leading up to event. } \\ 8\end{array} & \text { Scoria cone growth near Hillpiece, erupted without warning. } \\ 8 & \text { Four months of earthquakes felt at the Settlement, but volcano never breaks the surface. } & \text { MEDIUM } \\ \end{array}$

the group to discuss assumptions, examine responses and consider measures to reduce risk. The group was able to independently explore many of the physical, economic, cultural and social components of vulnerability and resilience identified earlier in the study. Although Hicks asked questions to prompt this discussion, the analysis was driven by the participants (Table 5).

The scenario planning exercise brought to the forefront hazards, risks and outcomes that had remained psychologically distant to the islanders, probably due both to lack of knowledge and denial of the issues. By framing the problem in a way that focussed on actions, resources and individual and collective responses, rather than the "science", workshop participants were engaged and were keen to participate. Several reflected that the scenario planning framework would be readily transferrable to multi-hazard scenarios and to the identification of other risks on Tristan

Evaluating the effectiveness of the scenario planning approach was conducted qualitatively, by observing the changes made as a result of the workshop. Modifications to behaviour and protocol provided an evidence base for successful communication as the "audience" are required to both understand the message and see it as personally relevant (Walker and Meyer, 1980; Morgan et al., 2002).

\subsection{Summary of outcomes}

The island council devised a large number of recommendations from the workshop; indicative of the many actions and resources required to plan for an eruptive crisis and mitigate the impacts and risk, should an eruption ensue ${ }^{12}$ (Table 3). Recommendations were mainly focussed on the need to reduce uncertainty and to provide effective early warnings by improved monitoring. However, in the absence of permanent monitoring stations, workshop participants realised the importance of increasing on-island capability.

\footnotetext{
${ }^{12}$ Discussions were all recorded. The summary here is based on verbatim records and not reproduced in full.
}

Recommendations focussed on protocol amendments, infrastructure and resource improvements.

One of the questions raised during stage one of the first scenario (Table 5), following felt earthquakes at the Settlement, was simply about whom to contact. Until then, no one was sure whom to call. As a result, the disaster management plan was updated to include contact details of appropriate personnel at the British Geological Survey (BGS), and the disaster management coordinator on Tristan and head of volcanology at BGS made direct contact.

By discussing each scenario and exploring the effects that external factors would have on response (e.g. poor weather), the workshop prompted the discussion and clarification of roles, amendments to the disaster management plan and design changes to the disaster management centre. Other infrastructure recommendations were suggested, including the active exploration of the role of Nightingale Island as a temporary off-island evacuation site (Table 3 ).

Since project completion, there is evidence of sustained interest in volcanic risk reduction from island administrators and FCO officials (Table 3). Annual meetings between the authors and FCO officials continue to be held two years postproject to maintain knowledge transfer and help implement recommendations as administrators and FCO officials move roles (there have been three different administrators and desk officers since project commencement in 2009). Sustained links with community members and the UK-based Tristan community have helped to prolong an interest in volcanic risk reduction, although longer-term dialogue on risk and resources will be needed to maintain this. This includes capacity building in terms of monitoring. The British Geological Survey retain responsibility for monitoring and providing initial response to volcanic and tectonic activity affecting Tristan; however, like many island volcanoes, effective monitoring is inadequate (one IRIS (Incorporated Research Institutions for Seismology) seismometer) and resources are limited. 
Table 5. Scenarios chosen for discussion. Stages of each scenario are outlined (separations indicate pauses for discussion). Questions and a list of considerations, discussed at each stage, are summarised.

\begin{tabular}{|c|c|c|}
\hline Scenario summary & Stage & Question prompts (each scenario; each stage) \\
\hline $\begin{array}{l}\text { Four months of earthquakes felt } \\
\text { at the Settlement, but a volcano } \\
\text { never breaks the surface (low } \\
\text { risk) }\end{array}$ & $\begin{array}{l}\text { It is a normal working day, earthquake is } \\
\text { felt in the village and objects move on } \\
\text { desks and shelves } \\
\text { The earthquakes increase in frequency over } \\
\text { the next } 4 \text { months. They can be felt all } \\
\text { over the island. There are some associated } \\
\text { rockfalls and some damage to homes and camping huts. } \\
\text { The earthquakes suddenly come to a } \\
\text { complete stop, none are felt again and no } \\
\text { volcano breaks the surface. }\end{array}$ & $\begin{array}{l}\text { What is the general response? } \\
\text { What is the administrator's response? } \\
\text { Considerations: } \\
\text { - Mobilising outside help } \\
\text { - Bad weather/seas } \\
\text { - Building damage (factory; residential and non-residential) } \\
\text { - Hospital patients? How to care for/move? } \\
\text { - Health and injuries (particularly agitated asthma and } \\
\text { arthritis) } \\
\text { - Harbour damage } \\
\text { - Damaged water supply } \\
\text { - Road washout }\end{array}$ \\
\hline $\begin{array}{l}\text { Scoria cone growth near } \\
\text { Hillpiece, erupted without } \\
\text { warning (medium risk) }\end{array}$ & $\begin{array}{l}\text { A large crack opens up on the road to the } \\
\text { Patches, between the cliff and Hillpiece. } \\
\text { Small rocks (scoria) start erupting from the } \\
\text { crack and build up a cone. As soon as the } \\
\text { eruption starts, earthquakes are felt at the } \\
\text { Settlement and at the Patches. } \\
\text { The eruption continues for the next week } \\
\text { and a volcanic mound is built almost } 40 \mathrm{~m} \\
\text { in height. Ash and rock are blown towards } \\
\text { the Settlement. }\end{array}$ & $\begin{array}{l}\text { - Dealing with media } \\
\text { - Contact with family and friends outside of Tristan } \\
\text { - Insufficient time to bring out scientist(s) } \\
\text { - No ship due for at least } 1 \text { month } \\
\text { - Insurance } \\
\text { - Effects of volcanic activity on flora and fauna } \\
\text { - Vehicles required to aid evacuation } \\
\text { - Machinery availability } \\
\text { - Boat mobilisation; ship arrivals } \\
\text { - Animal care } \\
\text { - People in different places around the island (e.g. the Patches) }\end{array}$ \\
\hline $\begin{array}{l}\text { Explosive eruption from summit, } \\
\text { with volcanic bombs (rocks) } \\
\text { reaching the edge of the Base. } \\
\text { Ash clouds erupted and ground } \\
\text { collapse occurs. } 2 \text { weeks of } \\
\text { earthquakes (high risk). }\end{array}$ & $\begin{array}{l}\text { Earthquakes increase in intensity and } \\
\text { frequency for the next } 2 \text { weeks and can be } \\
\text { felt all over the island. Rockfalls cause } \\
\text { damage to homes and the roads begin to } \\
\text { crack and buckle. }\end{array}$ & \\
\hline
\end{tabular}

\section{Conclusions}

In any volcanic setting, it is important to identify and understand the most salient components of risk. This research adopted an integrated, interdisciplinary approach to reducing volcanic risk on Tristan da Cunha. By examining all components concurrently, this approach drew attention to the complexity of volcanic risk and yet in doing so made anticipating the relationships between different components clearer. Conclusions from the probabilistic, physical and social science components (to address objectives $\mathrm{i}$ and ii) are briefly summarised below.

Understanding the time-size distribution of volcanic eruptions provides an important first step in volcanic hazard assessments. The new field observations from Tristan provided a more precise geochronology of the recent eruptive history $(<80 \mathrm{kyr})$. Results show that there is no spatio-temporal pattern to parasitic centre activity on Tristan, and suggest that magmatism is not dominated by one large chamber but, rather, smaller individual pockets of magma that source rapidly from depth. These findings demonstrate the variability of eruption style, volume, composition and location, and present significant uncertainty in anticipating future eruptive scenarios.
To quantify this uncertainty, these data were presented in an expert elicitation exercise. Results describe the extent to which experts were uncertain about the likely location of future eruptions and demonstrated that the absence of records of proximal monitoring data, in particular, contributed to great uncertainty as to whether registered "unrest" would lead to an eruption. Nonetheless the consensus, reached via a weighted mean of responses, showed that the consensus view was that the likely location of the next eruption would be the coastal strips. However, the associated uncertainty around each scenario was very large (Table 1).

Results of the ethnographic reconnaissance suggest that, while, on one hand, location and seclusion have contributed to vulnerability to natural hazards, on the other hand they have also led to the formation of successful coping mechanisms (Lewis, 1999; Howorth, 2005; Kelman and Mather, 2008). The relationship between these two processes has in the past been relatively balanced in that the community has been able to cope under uncertain conditions and recover from traumatic events, most notably the 1961-1962 eruption. Adjustment to new circumstances, such as the introduction of formal governance and of modern communication technologies, has undoubtedly affected the vulnerabilityresilience balance. By examining the temporal dynamics of 
vulnerability and resilience on Tristan, it was possible to guide a scenario planning exercise to allow decision makers to consider community capacity to cope with a future eruptive crisis.

The results from this research demonstrated the need for broader and deeper understandings of incomplete knowledge, both for Tristan and at other settings. This requires different approaches that complement quantitative risk analysis, such as participatory and deliberative procedures (Stirling, 2010). In the absence of even a partially complete data set (lack of monitoring data), a scenario planning approach was selected as the most suitable method for discussing volcanic risk and evaluating responses on Tristan. Both short-term practical solutions and longer-term strategies were recommended as a result of the scenario exercise. Many have already been implemented, for example updates to the disaster management plan and design alterations to the disaster management centre. An offshore evacuation drill is planned for November 2014, and will be designed to respond to a rapidonset eruptive scenario that threatens the Settlement.

The continuing challenge for Tristan will be to consider and address this changing vulnerability-resilience balance in order to maintain appropriate risk reduction measures. In order to sustain its capacity for resilience in the face of volcanic hazards, it will be important for the community to take the lead in considering possible new futures and to design and revise disaster management programmes that are suitable for both the present day and future needs and capabilities of the islanders.

\section{Reflections on the interdisciplinary approach and transferability to other settings}

Significant experience shows that decisions by governments and civil society to enhance resilience require scientific knowledge to be credible, salient and legitimate (Cash et al., 2002), and that research evidence and scientific knowledge comprise only one factor influencing the formulation of strategies to reduce risk.

One conclusion that we can draw from our experience with this project is that the success of this interdisciplinary approach required, at the project outset, that we took time not only to understand the unique social context and dynamics in order to establish the most salient components of the social system, but also to integrate this knowledge with information about the volcanic system. Ideally, the type of expertise required for effective interdisciplinary approaches to volcanic risk reduction include subject matter experts (volcanologists), decision scientists who can identify and quantify uncertainties and social scientists who apply a range of methods to engage with the public at risk and understand the social sources of vulnerability and resilience. This type of expertise can be embodied by an interdisciplinary team or, as demonstrated here, by a lone researcher. Although a larger research team was not necessary, or even suitable, for the very particular setting of the Tristan study, the interdisciplinary framework that we have developed could readily be employed for multi-researcher studies of larger scale and longer duration.

Ultimately, actions to reduce risk are taken and owned by communities at risk. Therefore, engagement and communication strategies need to be tailored to the particular social and hazard context and, ideally, need to be designed in collaboration with those at risk. Tackling the communication challenges successfully therefore requires practitioners with an understanding of physical processes; the ability to handle scientific uncertainty; and an aptitude and desire to take an inclusive, collaborative approach to communicating in ways adapted to specific hazard and social contexts (e.g. Stirling, 2010; Pidgeon and Fischhoff, 2011). Further, while features such as functional competence, legitimacy, fairness and openness are known to increase trust and thereby the effectiveness of risk communication (e.g. Haynes et al., 2008a), experience on Tristan also highlighted the importance of interpersonal competence (Gabarro, 1978) of the communicator when interacting with small communities, in order to build - for example through empathy, amiability, enthusiasm and readiness to participate - positive interpersonal relationships. It seems likely therefore that the islanders would not have been so inclined to participate if the field seasons had been considerably shorter and personal interaction less. Similarly, the willingness and enthusiasm of the island council to discuss volcanic hazards and risk reduction measures, as well as of the wider community to conduct an evacuation drill, was undoubtedly encouraged by regular discussion of both the volcano and possible future eruptive scenarios by the researcher.

In all of this the scenario planning strategy was of central importance, in that as a decision support tool it was well suited to the high degree of scientific uncertainty; was a vehicle for interdisciplinary integration; and provided a procedure for stakeholder engagement, deliberation and learning.

Reducing volcanic risk is a complex and nuanced process. The first step in this process is a more sophisticated understanding of risk and acknowledgement that this can change. This study provides a template for the integration of disciplinary knowledge production into an interdisciplinary perspective on risk and the means to share that understanding with those who need to act.

Acknowledgements. This research was funded by a joint Natural Environment Research Council (NERC)-Economic Research Council (ESRC) studentship, the British Geological Survey University Funding Initiative and a NERC grant (IP-1152-1109). The authors wish to thank the Tristan islanders, Tristan Government and the UK Foreign and Commonwealth Office for supporting and sanctioning research on the island. The authors would also like to acknowledge the support of the "Strengthening Resilience in Volcanic Areas" project (www.streva.ac.uk) in the writing of 
this paper. Lastly we are grateful to the editor and two anonymous reviewers for constructive suggestions to improve this manuscript.

Edited by: G. Le Cozannet

Reviewed by: two anonymous referees

\section{References}

Anderson, M. B. and Woodrow, P. J.: Rising from the ashes: development strategies in times of disaster, Westview Press, Boulder, p. 338, 1989.

Aspinall, W. and Cooke, R. M: Expert Judgement and the Montserrat Volcano eruption, in: Proceedings of the 4th International Conference on Probabilistic Safety Assessment and Management PSAM4, Vol. 3, 13-18 September 1998, New York City, USA, 2113-2118, 1998.

Baker, P. E., Gass, I. G., Harris, P. G., and Le Maitre, R. W: The volcanological report of the Royal Society expedition to Tristan da Cunha, 1962, Philos. T. Roy. Soc. Lond. A, 256, 439-575, 1964.

Barclay, J., Haynes, K., Mitchell, T., Solana, C., Teeuw, R., Darnell, A., Crosweller, S., Cole, P., Pyle, D., Lowe, C., Fearnley, C., and Kelman, I: Framing volcanic risk communication within disaster risk reduction: finding ways for the social and physical sciences to work together, in: Communicating Environmental Geoscience, Vol. 305, edited by: Liverman, D., Pereira, C., and Marker, B., Special Publications, Geological Society, London, 163-177, 2008.

Brander, J: Tristan da Cunha, 1506-1902, G. Allen \& Unwin Ltd, London, 1940.

Cash, D., Clark, W. C., Alcock, F., Dickson, N. M., Eckley, N., and Jäger, J.: Salience, Credibility, Legitimacy and Boundaries: Linking Research, Assessment and Decision Making, KSG Working Papers Series RWP02-046, Harvard Kennedy School of Government, Cambridge, Massachussetts, doi:10.2139/ssrn.372280, 2002.

Chester, D. K.: Theology and disaster studies: The need for dialogue, J. Volcanol. Geoth. Res., 146, 319-328, 2005.

Chester, D. K., Duncan, A. M., and Dibben, C. J. L.: The importance of religion in shaping volcanic risk perception in Italy, with special reference to Vesuvius and Etna, J. Volcanol. Geoth. Res., 172, 216-228, 2008.

Coleman, J: Foundations of Social Theory, Harvard University Press, Cambridge, 1990.

Cooke, R. M.: Experts in uncertainty: opinion and subjective probability in science, Oxford University Press, New York, 1991.

Cooke, R. M.: Special issue on expert judgment, Reliabil. Eng. Syst. Safe., 93, 655-656, 2008.

Cooke, R. M. and Goosens, L. J. H.: Procedures Guide for Structured Expert Judgment, Technical report EUR 18820 EN, European Commission, Directorate-General for Research, Brussels, Belgium, 1999.

Cronin, S. J., Gaylord, D. R., Charley, D., Alloway, B. V., Wallez, S., and Esau, J. W: Participatory methods of incorporating scientific with traditional knowledge for volcanic hazard management on Ambae Island, Vanuatu, Bull. Volcanol., 66, 652-668, 2004.

Dibben, C. J. L. and Chester, D. K.: Human vulnerability in volcanic environments: the case of Furnas, Sao Miguel, Azores, J. Volcanol. Geoth. Res., 92, 133-150, 1999.
Donovan, K. H. M.: Cultural responses to volcanic hazards on Mt Merapi, Indonesia, Ph.D. Thesis, University of Plymouth, Plymouth, 2010.

Dunkley, P.: Volcanic hazard assessment of Tristan da Cunha, British Geological Survey Commissioned Report CR/02/146N, British Geological Survey, Keyworth, Nottingham, 2002.

Gabarro, J.J: The development of trust, influence and expectations, in: Interpersonal behaviors: Communication and understanding in relationships, edited by: Athos, A. G. and Gabarro, J. J., Prentice Hall, Englewood Cliffs, NJ, 290-303, 1978.

Gaillard, J.-C.: Resilience of traditional societies in facing natural hazards, Disaster Prevent. Manage., 16, 522-544, 2007.

Gaillard, J.-C.: Alternative paradigms of volcanic risk perception: The case of Mt. Pinatubo in the 786 Philippines, J. Volcanol. Geoth. Res., 172, 315-328, 2008.

Gregg, C. E., Houghton, B. F., Johnston, D. M., Paton, D., and Swanson, D. A.: The perception of volcanic risk in Kona communities from Mauna Loa and Hualalai volcanoes, Hawaii, J. Volcanol. Geoth. Res., 130, 179-196, 2004.

Hards, V: Assessment of volcanic activity in the wake of the seismic episode of 29/30 July 2004 on Tristan da Cunha, South Atlantic Ocean, British Geological Survey Commissioned Report CR/04/235, British Geological Survey, Keyworth, Nottingham, 2004.

Haynes, K., Barclay, J., and Pidgeon, N.: Volcanic hazard communication using maps: an evaluation of their effectiveness, Bull. Volcanol., 70, 123-138, 2007.

Haynes, K., Barclay, J., and Pidgeon, N.: The issue of trust and its influence on risk communication during a volcanic crisis, Bull. Volcanol., =70, 605-621, 2008a.

Haynes, K., Barclay, J., and Pidgeon, N.: Whose reality counts? Factors affecting the perception of volcanic risk, J. Volcanol. Geoth. Res., 172, 259-272, 2008b.

Hicks, A., Barclay, J., Mark, D. F., and Loughlin, S.: Tristan da Cunha: Constraining eruptive behavior using the ${ }^{40} \mathrm{Ar} /{ }^{39} \mathrm{Ar}$ dating technique, Geology, 40, 723-726, doi:10.1130/G33059.1, 2012.

Hicks, A., Barclay, J., Simmons, P., and Loughlin, S.: Trial and examination of expert elicitation for appraising eruption hazards in an ill-defined volcanic setting, in preparation, 2014.

Holcomb, R. T. and Searle, R. C: Large landslides from oceanic volcanoes, Mar. Georesour. Geotech., 10, 19-32, 1991.

Holling, C.: Understanding the complexity of economic, ecological, and social systems, Ecosystems, 4, 390-405, 2001.

Howorth, R: Islands, Isolation and Vulnerability, in: International Strategy for Disaster Reduction: Leicester and Geneva, edited by: Risk, K., Tudor Rose Publications and the International Strategy for Disaster Reduction, Leicester, Geneva, 224-227, 2005.

Johnson, D. M.: The role of multidisciplinary research and collaboration for improving the resilience of communities to volcanic risk, J. Appl. Volcanol., 1, 1, doi:10.1186/2191-5040-1-1, 2012.

Kelman, I.: Sustainable Livelihoods from Natural Heritage on Islands, Island Stud. J., 2, 101-114, 2007.

Kelman, I. and Mather, T. A.: Living with volcanoes: The sustainable livelihoods approach for volcano-related opportunities, J. Volcanol. Geoth. Res., 172, 189-198, 2008. 
Lanphere, M., Champion, D., Melluso, L., Morra, V., Perrotta, A., Scarpati, C., Tedesco, D., and Calvert, A.: ${ }^{40} \mathrm{Ar} /{ }^{39} \mathrm{Ar}$ ages of the AD 79 eruption of Vesuvius, Italy, Bull. Volcanol., 69, 259-263, 2007.

Le Roex, A. P., Cliff, R. A., and Adair, B. J. I.: Tristan da Cunha, South Atlantic: Geochemistry and Petrogenesis of a BasanitePhonolite Lava Series, J. Petrol., 31, 779-812, 1990.

Lewis, J.: Development in Disaster-prone Places, Intermediate Technology Publication, Studies of Vulnerability, London, 1999.

Lewis, J.: An Island Characteristic. Derivative vulnerabilities to indigenous and exogenous hazards, Shima, 3, 3-15, 2009.

McDougall, I. and Ollier, C. D.: Potassium-argon ages from Tristan da Cunha, South Atlantic, Geolog. Mag., 119, 87-93, 1982.

Mercer, J., Dominey-Howes, D., Kelman, I., and Lloyd, K.: The potential for combining indigenous and western knowledge in reducing vulnerability to environmental hazards in small island developing states, Environ. Hazards, 7, 245-256, 2007.

Morgan, M. G., Fischhoff, B., Bostrum, A., and Atman, C. J.: Risk Communication - A Mental Models Approach, Cambridge University Press, Cambridge, 2002.

Munch, P. A.: Culture and superculture in a displaced community: Tristan da Cunha, Ethnology, 3, 369, 1964.

Munch, P. A.: Economic Development and Conflicting Values: A Social Experiment in Tristan da Cunha, Am. Anthropol., 72, 1300-1318, 1970.

Munch, P. A.: Crisis in Utopia: The Ordeal of Tristan da Cunha, New York, Thomas Y. Crowell Company, New York, 1971.

Murphy, B.: Locating social capital in resilient community-level emergency management, Nat. Hazards, 41, 297-315, 2007.

O’Mongain, A. M., Baptie, B. J., Booth, D. C., Flower, S. M., Ford, G. D., Galloway, D. D., Ottemoller, L., and Simpson, B. A.: Seismic activity in the region of Tristan da Cunha, October 2004February 2005, British Geological Survey Commissioned Report cr/05/052, British Geological Survey, Keyworth, Nottingham, 43 pp., 2005.

Paton, D., Millar, M., and Johnston, D.: Community Resilience to Volcanic Hazard Consequences, Nat. Hazards, 24, 157-169, 2001.

Paton, D., Smith, L., Daly, M., and Johnston, D.: Risk perception and volcanic hazard mitigation: Individual and social perspectives, J. Volcanol. Geoth. Res., 172, 179-188, 2008.

Pelling, M. and High, C.: Understanding adaptation: What can social capital offer assessments of adaptive capacity?, Global Environ. Change Pt. A, 15, 308-319, 2005.

Pelling, M. and Uitto, J. I.: Small island developing states: natural disaster vulnerability and global change, Global Environ. Change Pt. B, 3, 49-62, 2001.
Pidgeon, N. and Fischhoff, B.: The role of social and decision sciences in communicating uncertain climate risks, Nat. Clim. Change, 1, 35-41, 2011.

Poortinga, W. and Pidgeon, N.: Exploring the Dimensionality of Trust in Risk Regulation, Risk Analysis, 23, 961-972, 2003.

Putnam, R.: Making Democracy Work: Civic Traditions in modern Italy, Princeton University Press, Princeton, 1993.

Putnam, R.: Bowling Alone: The Collapse and Revival of American Community, Simon \& Schuster, New York, 2000.

Reagan, M. K., Turner, S., Legg, M., Sims, K. W. W., and Hards, V. L.: ${ }^{238} \mathrm{U}$ - and ${ }^{232} \mathrm{Th}$-decay series constraints on the timescales of crystal fractionation to produce the phonolite erupted in 2004 near Tristan da Cunha, South Atlantic Ocean, Geochim. Cosmochim. Acta, 72, 4367-4378, 2008.

Renne, P. R., Sharp, W. D., Deino, A. L., Orsi, G., and Civetta, L.: ${ }^{40} \mathrm{Ar} /{ }^{39} \mathrm{Ar}$ Dating into the Historical Realm: Calibration Against Pliny the Younger, Science, 277, 1279-1280, 1997.

Rubin, O. and Rossing, T.: National and local vulnerability to climate-related disasters in Latin America: The role of social asset-based adaptation, B. Lat. Am. Res., 31, 19-35, 2012.

Sleep, N.: Hotspots and mantle plumes: some phenomenology, J. Geophys. Res., 95, 6715-6736, 1990.

Slutsky, A. S., Zamel, N., and University Of Toronto Genetics of Asthma Research Group: Genetics of Asthma: The University of Toronto Program, Am. J. Respir. Crit. Care Med., 156, 130-132, 1997.

Stirling, A.: Risk, uncertainty and precaution: some instrumental implications from the social sciences, in: Negotiating Environmental Change, New Perspectives from Social Science, edited by: Berkhout, F., Leach, M., and Scoones, I., Edward Elgar, Cheltenham, 33-76, 2003.

Stirling, A.: Keep it complex: Nature, 468, 1029-1031, 2010.

Twigg, J.: Sustainable livelihoods and vulnerability to disasters, Disaster Management Working Paper, Benfield Greig Hazard Research Centre, University College London, London, 2001.

Walker, C. H. and Meyer, B. J. F.: Integrating different types of information in text, J. Verb. Learn. Verb. Behav., 19, 263-275, 1980.

Wolcott, H. F.: Ethnography: a way of seeing, AltaMira Press, Lanham, p. 335, 1999.

Zamel, N., McClean, P. A., Sandell, P. R., Siminovitch, K. A., and Slutsky, A. S.: Asthma on Tristan da Cunha: looking for the genetic link. The University of Toronto Genetics of Asthma Research Group, Am. J. Respir. Crit. Care Med., 153, 1902-1906, 1996. 